\title{
Motivasi Berhenti Merokok pada Perokok Dewasa Muda Berdasarkan Transtheoretical Model (TTM)
}

Esti Rossa Larasati, Wita Saraswati, Henny Utami Setiawan, Silda Sabila Rahma, Agustina Gianina, Cindy Alicia Estherline, Fitri Nurmalasari, Nauri Nabiela Annisa, Indah Septiani, Gesnita Nugraheni*

Program Studi Pendidikan Apoteker, Fakultas Farmasi, Universitas Airlangga, Surabaya

*Corresponding author: gesnita-n@ff.unair.ac.id

\begin{abstract}
Background: Smoking is known as one of risk factors contributes to many diseases and mortality. Nevertheless, there is increase of the prevalence of young age smokers. Intervention to quit smoking is important to be conducted effectively. The intervention design of smoking cessation could be interfered by the intensity of motivation to quit smoking. Objectives: The study aimed to to identify the motivation to quit smoking based on the Transtheoretical Models (TTM), to determine the relationship of demography factors and knowledge related to motivation to quit smoking, and to see factors that distinguished motivation to quit smoking. Methods: This research was conducted around Universitas Airlangga Campus B on September 2018 using a survey method, a cross-sectional study design with an accidental sampling. Results: Participants in this study were smokers aged 17 - 25 years $(n=162)$. The result shows that the most motivation stage found was contemplation (38\% or 62 respondents). Contemplation is the stage where smokers already have the desire to quit smoking in the next 6 months, so still has a tendency to not quit smoking. The demographics profiles as student income, number of smoker friends who smoke, the existence of smokers around their housing area, did not significantly influence the motivation stage to quit smoking. Knowledge and smoking intensity had a significant effect on the motivation to quit smoking. There was a correlation between the amount of budgeting on smoking and the number of cigarettes per day with the motivation to quit smoking $(p=0.000)$. Conclusion: Health promotion focusing on quit smoking on young adults is urgent to be conducted. Intervention that can be done for smokers at the contemplation stage is giving information about the dangers of smoking and information about NRT (Nicotine Replacement Therapy).
\end{abstract}

Keywords: smoker, motivation, TTM, quit smoking

\begin{abstract}
Abstrak
Pendahuluan: Merokok telah diketahui menjadi faktor resiko banyak penyakit dan kematian. Meskipun demikian, terdapat peningkatan prevalensi perokok berusia muda. Intervensi untuk meningkatkan angka berhenti merokok diharapkan efektif dilakukan. Desain intervensi tersebut dapat dipengaruhi oleh seberapa tinggi motivasi berhenti merokok. Tujuan: Penelitian ini dilakukan dengan tujuan untuk mengidentifikasi motivasi seseorang untuk berhenti merokok berdasarkan Transtheoretical Model (TTM), untuk menentukan hubungan faktor demografi dan pengetahuan rokok terhadap motivasi berhenti merokok, dan menemukan faktor-faktor yang membedakan motivasi untuk berhenti merokok. Metode: Penelitian ini dilakukan di sekitar kampus B Universitas Airlangga pada September 2018 menggunakan metode survei, rancangan studi cross-sectional dengan teknik accidental sampling. Responden dalam penelitian ini merupakan perokok berusia 17 - 25 tahun (n = 162). Hasil: Dari hasil analisis data diperoleh bahwa tingkat motivasi tertinggi terdapat pada tahap kontemplasi yaitu sebanyak 38,9\% (62 responden). Tahap kontemplasi adalah tahap dimana seseorang masih berstatus sebagai perokok aktif, tetapi sudah berkeinginan untuk berhenti merokok dalam 6 bulan ke depan, sehingga masih memiliki kecenderungan untuk membatalkan keinginan berhenti merokok. Profil demografi, seperti uang saku, jumlah teman merokok dan keberadaan perokok di rumah responden tidak berpengaruh signifikan terhadap tingkat motivasi berhenti merokok. Pengetahuan dan intensitas merokok berpengaruh signifikan terhadap motivasi berhenti merokok. Terdapat korelasi antara pengeluaran untuk merokok dan jumlah batang rokok per hari dengan motivasi berhenti merokok $(\mathrm{p}=0,000)$. Kesimpulan: Promosi kesehatan terkait berhenti merokok
\end{abstract}


yang berfokus di kalangan remaja sangat perlu dilakukan. Intervensi yang dapat dilakukan untuk perokok pada tahap kontemplasi adalah mengadakan penyuluhan tentang bahaya merokok dan pemberian informasi adanya NRT (Nicotine Replacement Therapy).

Kata kunci: perokok, motivasi, transtheoretical model (TTM), berhenti merokok

\section{PENDAHULUAN}

Rokok mengandung lebih dari 7000 zat kimia toksik dan mengiritasi (CDC, 2018). Terdapat setidaknya 250 senyawa berbahaya termasuk senyawa hidrogen sianida, karbon monoksida, dan amonia. Rokok juga mengandung nikotin yang dapat menimbulkan adiksi pada perokok, serta zat karsinogenik seperti tar (Hatsukami dkk., 2008). Data Survei Sosial Ekonomi Nasional (Susenas), ada peningkatan prevalensi perokok usia lebih dari 15 tahun, yaitu 27\% (Kementerian Kesehatan RI, 2015). Pada tahun 2015, sekitar 72 juta dari 184 juta populasi dengan usia lebih dari 15 tahun merupakan perokok (WHO, 2015). Usia rata-rata mulai merokok setiap hari adalah 17,6 tahun (WHO, 2018).

Rokok membunuh sekitar 225.720 orang per tahun atau sekitar $14,7 \%$ dari angka kematian total. Sebagian besar kasus kematian perokok disebabkan oleh beberapa penyakit akibat rokok, seperti penyakit kardiovaskular sebesar $65 \%$, penyakit menular pada ibu dan bayi baru lahir serta penyakit nutrisi atau Communicable, Maternal, Neonatal, and Nutritional Diseases (CMNND) sebesar 11\%, dan penyakit saluran pernafasan kronis atau Chronic Respiratory Diseases (CRD) sebesar 9\%, kanker 5\%, dan lainnya 10\% (WHO, 2018).

Perokok berisiko terkena kanker paru sepuluh kali lebih besar dibandingkan dengan orang yang tidak merokok karena terlalu banyak terpapar senyawa karsinogenik (Jacob dkk., 2014; Helen dkk., 2015). Sekitar $80 \%$ sampai $90 \%$ penderita kanker paru di Amerika Serikat disebabkan oleh merokok. Perokok juga memiliki $30-40 \%$ risiko lebih tinggi terkena diabetes. Prevalensi katarak di kalangan perokok ditemukan sebesar 52,60\%. Pengguna tembakau dalam bentuk apapun ditemukan memiliki prevalensi katarak lebih tinggi sebesar 67,57\% (Raju dkk., 2006).

Menurut World Health Organization (WHO), di Indonesia prevalensi perokok berusia $15-24$ tahun memiliki tren yang meningkat. Pada tahun 2000 prevalensi perokok pada usia tersebut sebesar $23,5 \%$, pada tahun 2010 meningkat menjadi $28 \%$ dan proyeksi pada tahun 2025 akan menjadi 38,8\% (WHO, 2015). Salah satu upaya untuk menekan angka perokok di
Indonesia adalah perlu dilakukan promosi kesehatan mengenai perilaku dan metode berhenti merokok. Perilaku berhenti merokok dapat dipengaruhi oleh beberapa faktor. Dari penelitian Ardita (2016), dinyatakan bahwa beberapa faktor yang menyebabkan perokok berhenti merokok, yaitu adanya dorongan atau dukungan sosial dari orang terdekat (orang tua, teman sebaya, kepribadian, dan media informasi yang mengiklankan tentang rokok); kontrol diri; tingkat ekonomi/pekerjaan yang dimiliki dan; kesadaran terhadap pentingnya kesehatan dan bahaya merokok terhadap diri sendiri serta lingkungannya.

Salah satu metode yang dapat memudahkan seseorang berhenti merokok adalah menjalani terapi farmakologi, yaitu dengan terapi pengganti nikotin atau Nicotine Replacement Therapy (NRT). Prinsip dasar NRT adalah dengan menggantikan nikotin dalam tubuh dengan selain rokok, sehingga dapat mengurangi gejala-gejala berhenti merokok, seperti depresi, mudah marah, cemas, sakit kepala dan perubahan nafsu makan (WHO, 2016). NRT tersedia dalam beberapa bentuk sediaan, yaitu nikotin transdermal, permen karet, tablet hisap, tablet sublingual, inhaler, dan obat semprot nasal (Rau, 2002).

Sebelumnya, terdapat penelitian Sieminska dkk. (2008) terkait motivasi dan metode untuk berhenti merokok. Dari penelitian tersebut, diperoleh bahwa motivasi terbesar untuk berhenti merokok adalah dari adanya kesadaran tentang kesehatan yaitu sebesar $57 \%$. Penelitian mengenai motivasi dan metode untuk berhenti merokok tersebut didasari oleh konsep Transtheoretical Model (TTM) yang dikembangkan oleh Prochaska \& Diclemente (1984). Terdapat 5 tahapan TTM, yaitu pre-contemplation (tidak berpikir untuk berhenti merokok), contemplation (berpikir untuk berhenti merokok dalam 6 bulan kedepan), preparation (berpikir untuk berhenti merokok dalam 30 hari kedepan), action (sudah berhenti merokok dalam 6 bulan), dan maintenance (sudah berhenti merokok lebih dari 6 bulan) (Diclemente dkk., 1991). Pada penelitian Etter \& Sutton (2002) juga digunakan konsep TTM dan hasilnya banyak responden yang berada pada tahap contemplation. 
Selain penelitian-penelitian tersebut, terdapat beberapa jurnal dari berbagai negara yang juga menggunakan TTM. Sarbandi dkk. (2013) melakukan penelitian menggunakan kuesioner transtheoretical model (TTM) untuk meneliti keinginan berhenti merokok berdasarkan sifat psikometrik di Iran. Robinson \& Vail (2012) juga melakukan tinjauan integratif terhadap penghentian merokok pada remaja menggunakan Transtheoretical Model, serta di Turkey, Güngörmüs \& Erci (2012) mengevaluasi efek dari pengajaran berbasis TTM kepada anak SMA untuk berhenti merokok. Diperoleh hasil bahwa pelatihan pada program berhenti merokok efektif dalam mengubah perilaku merokok.

Penelitian ini menggunakan konsep TTM (Transtheoretical Model) dengan tujuan mengetahui hubungan antara profil demografi dan tingkat pengetahuan tentang bahaya merokok pada perokok aktif di kalangan mahasiswa Kampus B Universitas Airlangga terhadap tahapan motivasi berhenti merokok yang nantinya dapat dijadikan pertimbangan dalam menentukan strategi promosi kesehatan untuk berhenti merokok.

\section{METODE}

\section{Desain penelitian dan teknik sampling}

Penelitian ini dilakukan dengan menggunakan studi cross sectional. Pengambilan data dilakukan dengan survei dan instrumen berupa kuesioner. Survei dilaksanakan di Kampus B Universitas Airlangga pada tanggal September 2018. Teknik sampling yang digunakan adalah accidental sampling yaitu responden terpilih adalah responden yang ditemui dan memenuhi kriteria inklusi. Berdasarkan tingkatan motivasi untuk berhenti merokok, responden digolongkan menjadi 5, yaitu (1) Pre-contemplation, (2) Contemplation, (3) Preparation, (4) Action, dan (5) Maintenance.

\section{Kriteria inklusi}

Kriteria inklusi yang ditetapkan adalah mahasiswa di Kampus B Universitas Airlangga usia 17 - 25 tahun, perokok dan bersedia menjadi responden dengan mengisi lembar penjelasan dan persetujuan.

\section{Instrumen dan skoring}

Instrumen penelitian berupa kuesioner yang merupakan modifikasi kuesioner mengenai penilaian tahapan perubahan untuk berhenti merokok oleh Velicer dkk. (1999). Kuesioner terdiri dari 3 bagian pertanyaan. Bagian A berisi tentang kondisi yang menyebabkan responden menjadi perokok yaitu: (1) Demografi, meliputi usia, jenis kelamin, asal fakultas, asal daerah, jumlah uang saku dalam sebulan; (2) Profil terkait merokok, meliputi jumlah teman yang merokok (sedikit/beberapa/banyak), keberadaan perokok di tempat tinggal responden (ada/tidak), frekuensi merokok (setiap hari/beberapa hari dalam seminggu/ pada saat tertentu), rata-rata jumlah rokok per hari dan pengeluaran untuk merokok dalam sehari (total uang yang dikeluarkan untuk membeli rokok). Bagian B berisi tentang pengetahuan perokok, untuk menguji pemahaman responden mengenai bahaya yang ditimbulkan dari merokok. Tingkat pengetahuan responden dinilai dengan rentang total skor 1 - 10 . Bagian $\mathrm{C}$ berisi pertanyaan yang mengacu pada kondisi motivasi berhenti merokok responden.

\section{Analisis data}

Analisis data deskriptif dengan menyajikan frekuensi dan persentase setiap tingkatan motivasi berdasarkan TTM, dilakukan menggunakan software IBM Statistical Product and Services Solution (SPSS) versi 21.

\section{HASIL DAN PEMBAHASAN}

Response rate (RR) sebesar 97\% dari total 167 calon responden. Karakteristik populasi sasaran ditunjukkan pada Tabel 1. Sejumlah 88,9\% responden masih berstatus sebagai perokok aktif. Sebagian besar dari responden memiliki banyak teman perokok $(92,6 \%)$ dan persentase keberadaan perokok di tempat tinggal responden sebesar $77,2 \%$, serta motivasi berhenti merokok dengan persentase tertinggi yaitu pada tahap kontemplasi sebanyak 62 responden $(38,9 \%)$.

Profil pengetahuan responden tentang bahaya merokok ditunjukkan pada Tabel 2. Dari data tersebut, diperoleh rata-rata skor responden sebesar 5,95. Diantara seluruh pertanyaan yang diajukan, sebagian besar responden mengetahui bahwa merokok dapat menyebabkan penyakit jantung dan kanker. Selain itu, mereka juga mengetahui bahwa rokok mengandung zat yang berbahaya yaitu nikotin dan tar. Sekitar 50\% responden telah menyadari bahwa perokok pasif memiliki risiko yang lebih besar daripada perokok aktif.

Pengaruh antara profil demografi dan pengetahuan responden terkait bahaya merokok terhadap motivasi berhenti merokok ditunjukkan pada Tabel 3. Dari hasil analisa data demografi responden, variabel uang saku bulanan $(p=0,416)$ yang dianalisis dengan uji beda Kruskal-Wallis, serta variabel jumlah teman yang merokok $(p=0,734)$ dan keberadaan perokok di tempat tinggal responden $(p=0,506)$ yang dianalisis dengan uji beda Chi Square menunjukkan bahwa 
jumlah responden pada ketiga variabel tersebut tidak jauh berbeda di antara tiap tingkatan motivasi berhenti merokok, sehingga variabel tersebut tidak berpengaruh signifikan terhadap tingkat motivasi berhenti merokok.

Pada penelitian ini diperoleh bahwa semakin rendah pengeluaran seseorang untuk merokok dan semakin sedikit jumlah pemakaian rokok per hari, maka semakin tinggi motivasi berhenti merokok. Hal ini dapat dilihat dari hasil analisis dengan uji korelasi Spearman yang menunjukkan adanya korelasi rendah dan bermakna antara pengeluaran untuk merokok dengan motivasi berhenti merokok $r(162)=-0,339$, $p=0,000$, serta korelasi sedang dan bermakna antara jumlah batang rokok per hari dengan motivasi berhenti merokok $r(162)=-0,477, p=0,000$.

Berdasarkan hasil analisis dengan uji beda Chi Square, pada variabel intensitas merokok, terdapat perbedaan jumlah responden yang bermakna pada tiap tingkat motivasi berhenti merokok dan dari hasil uji korelasi Spearman menunjukkan bahwa intensitas merokok berpengaruh secara signifikan terhadap motivasi berhenti merokok $(p=0,000)$, artinya semakin rendah intensitas merokok maka semakin tinggi motivasi untuk berhenti merokok, sedangkan pengetahuan terkait bahaya merokok tidak berpengaruh secara signifikan $(p=0,085)$ terhadap motivasi berhenti merokok dengan 5 kategori. Hal ini dimungkinkan karena jumlah kategori terlalu banyak dan jumlah sampel tidak mencukupi, sehingga dilakukan penyederhanaan pada kategori motivasi berhenti merokok menjadi 3 kategori sebagai berikut: (1) Pre-contemplation, (2) Contemplation dan preparation, (3) Action dan maintenance. Diperoleh hasil skor pengetahuan berpengaruh secara signifikan terhadap motivasi berhenti merokok $(p=0,021)$. Hal ini dapat diartikan bahwa semakin tinggi pengetahuan perokok terkait bahaya merokok maka semakin tinggi pula motivasi nya untuk berhenti merokok. Oleh karena itu, salah satu upaya meningkatkan motivasi berhenti merokok dapat dilakukan dengan meningkatkan pengetahuan perokok tentang bahaya merokok serta cara berhenti merokok melalui kegiatan promosi kesehatan.

Promosi kesehatan ini memerlukan strategi yang sesuai dengan kondisi populasi sasaran yang didasarkan pada motivasi berhenti merokok. Terdapat penelitian serupa di Ontario bagian Timur, Kanada, yang menggunakan studi cohort dengan jumlah 760 responden. Kriteria inklusi dalam studi tersebut adalah perokok dewasa (minimal 18 tahun) dari masyarakat umum yang tinggal di Wilayah Ontario Timur berikut: Prince Edward, Hastings, Lennox and Addington, and Frontenac. Diperoleh hasil motivasi berhenti merokok tertinggi pada tahap kontemplasi, yaitu sebesar $68 \%$ (Pickett \& Bains, 1998). Serupa dengan penelitian tersebut, dari hasil survei ini diperoleh persentase tertinggi motivasi berhenti merokok pada tahap kontemplasi, yaitu sebesar 38,9\%. Responden yang berada di tahap ini masih berstatus sebagai perokok aktif, tetapi sudah ingin berhenti merokok dalam 6 bulan ke depan, sehingga masih memiliki kecenderungan untuk membatalkan keinginan mereka berhenti merokok. Padahal mereka masih berpeluang untuk menderita penyakit akibat merokok (Pickett \& Bains, 1998).

Terdapat beberapa strategi yang dapat dilakukan dalam promosi kesehatan, yaitu strategi stages based intervention dan strategi non stages based intervention. Strategi stages based intervention lebih berpengaruh daripada menggunakan strategi non stages based intervention (Cahil dkk., 2010). Strategi promosi kesehatan yang dapat digunakan untuk perokok pada tahap pra-kontemplasi dan kontemplasi adalah dengan mengedukasi bahaya merokok, pertimbangan biaya yang dikeluarkan untuk rokok, dan manfaat dari berhenti merokok. Perokok yang berada pada tahap persiapan dapat difasilitasi dengan cara meningkatkan pemahaman mengenai keuntungan dari berhenti merokok, mengedukasi tentang adanya NRT, petunjuk untuk berhenti (booklet, aplikasi HP), menetapkan jadwal untuk berhenti merokok. Bagi perokok pada tahap aksi, maka sebaiknya menghindari perokok lain, meminta dukungan dari orang sekitar, mengetahui efek yang terjadi saat berhenti merokok dan cara mengatasinya, serta menyibukkan diri. Untuk tahap pemeliharaan, maka harus mengontrol diri agar tidak merokok dan hidup bebas rokok (Canadian Cancer Society, 2013).

Peran yang dapat dilakukan oleh apoteker adalah mengadakan program promosi kesehatan. Program promosi kesehatan yang sesuai dengan responden pada tahap kontemplasi adalah mengadakan penyuluhan tentang bahaya merokok dan pemberian informasi mengenai adanya NRT. Diharapkan setelah mengikuti penyuluhan, perokok pada tahap ini semakin bertekad untuk berhenti merokok. Selain itu, untuk membantu para perokok berhenti merokok, apoteker dapat menjelaskan cara-cara berhenti merokok dan memberi solusi jika perokok mengalami kesulitan berhenti merokok. 
Tabel 1. Profil demografi responden

\begin{tabular}{|c|c|c|c|}
\hline Variabel & $\mathrm{n}(\%)$ & Variabel & $\mathrm{n}(\%)$ \\
\hline Jenis Kelamin & & Keberadaan Perokok di Tempat Tinggal & \\
\hline Laki-laki & $158(97,5 \%)$ & Ya & $125(77,2 \%)$ \\
\hline Usia & & Intensitas Merokok & \\
\hline \multirow{3}{*}{ Rata-rata $=21 \pm 1,95$} & & Setiap hari & $96(59,3 \%)$ \\
\hline & & Beberapa hari dalam seminggu & $24(14,8 \%)$ \\
\hline & & Pada saat tertentu & $42(25,9 \%)$ \\
\hline Uang saku & & Status Merokok & \\
\hline$<1$ juta/bulan & $62(38,3 \%)$ & Ya & $144(88,9 \%)$ \\
\hline 1 juta - 2 juta/bulan & $81(50,0 \%)$ & Pernah ( stop $\leq 6$ bulan) & $11(6,8 \%)$ \\
\hline 2 juta - 5 juta/bulan & $19(17,7 \%)$ & Pernah (stop > 6 bulan) & $7(4,3 \%)$ \\
\hline Pengeluaran untuk merokok & & Pengetahuan (nilai maksimal $=10$ ) & \\
\hline$\leq \mathrm{Rp} 10.000$ & $60(37,0 \%)$ & Rata-rata $6 \pm 1,45$ & \\
\hline Rp. 11.000 - Rp20.000 & $66(40,7 \%)$ & & \\
\hline Rp. 21.000 - Rp30.000 & $17(10,5 \%)$ & Jumlah Teman Perokok & \\
\hline Rp. 31.000 - Rp40.000 & $5(3,1 \%)$ & Banyak & $150(92,6 \%)$ \\
\hline Rp. 41.000 - Rp50.000 & $10(6,2 \%)$ & Beberapa & $11(6,8 \%)$ \\
\hline$>$ Rp. 50.000 & $4(2,5 \%)$ & $\begin{array}{l}\text { Beberapa } \\
\text { Sedikit }\end{array}$ & $1(2,6 \%)$ \\
\hline Jumlah rokok per hari & & Motivasi Berhenti Merokok* & \\
\hline$\leq 10$ & $101(62,3 \%)$ & Pre-Contemplation & $46(28,4 \%)$ \\
\hline $11-20$ & $48(29,6 \%)$ & Contemplation & $63(38,9 \%)$ \\
\hline $21-30$ & $9(5,6 \%)$ & Preparation & $41(25,3 \%)$ \\
\hline $31-40$ & $3(1,8 \%)$ & Action & $6(3,2 \%)$ \\
\hline$>40$ & $1(0,6 \%)$ & Maintenance & $6(3,2 \%)$ \\
\hline
\end{tabular}

* Pengelompokkan berdasarkan jawaban responden terkait rencana berhenti merokok

Pre-Contemplation : Tidak berencana untuk berhenti merokok

Contemplation : Berencana untuk berhenti merokok dalam 6 bulan ke depan

Preparation : Berencana untuk berhenti merokok dalam 30 hari ke depan

Action : Sudah berhenti merokok dalam kurun waktu 6 bulan

Maintenance : Sudah berhenti merokok lebih dari 6 bulan 
Tabel 2. Profil pengetahuan tentang bahaya merokok dan smoking cessation

\begin{tabular}{|c|c|}
\hline \multirow{2}{*}{ Pernyataan } & Jawaban \\
\hline & Salah \\
\hline Rokok dapat menyebabkan penyakit jantung & $26(16,04 \%)$ \\
\hline Rokok dapat menyebabkan penyakit Diabetes Melitus & $102(62,96 \%)$ \\
\hline Rokok dapat menyebabkan penyakit kanker & $20(12,35 \%)$ \\
\hline $\begin{array}{l}\text { Kebiasaan merokok mempunyai faktor risiko terhadap } \\
\text { penyakit katarak }\end{array}$ & $96(59,25 \%)$ \\
\hline $\begin{array}{l}\text { Perokok pasif adalah orang yang tidak merokok, tetapi } \\
\text { menghirup asap rokok dari orang yang merokok di } \\
\text { sekitarnya. }\end{array}$ & $13(8,02 \%)$ \\
\hline \multirow{2}{*}{ Pernyataan } & Jawaban \\
\hline & Salah \\
\hline $\begin{array}{l}\text { Perokok aktif memiliki risiko penyakit lebih besar } \\
\text { daripada perokok pasif }\end{array}$ & $80(49,38 \%)$ \\
\hline $\begin{array}{l}\text { Zat yang terkandung dalam rokok salah satunya adalah } \\
\text { nikotin dan tar }\end{array}$ & $6(3,71 \%)$ \\
\hline $\begin{array}{l}\text { Nikotin adalah zat yang menyebabkan kanker } \\
\text { (karsinogenik) }\end{array}$ & $119(73,46 \%)$ \\
\hline $\begin{array}{l}\text { Tar adalah zat bersifat adiktif yang dapat menyebabkan } \\
\text { ketergantungan }\end{array}$ & $116(71,61 \%)$ \\
\hline $\begin{array}{l}\text { Terdapat terapi pengganti nikotin dalam bentuk patch } \\
\text { (koyo) }\end{array}$ & $78(48,15 \%)$ \\
\hline
\end{tabular}

Keterangan: Benar $=$ sesuai kunci jawaban; salah $=$ tidak sesuai kunci jawaban

Tabel 3. Analisis hubungan variabel dengan motivasi berhenti merokok

\begin{tabular}{|c|c|c|c|c|c|c|c|}
\hline \multirow{3}{*}{ Variabel } & \multicolumn{5}{|c|}{ Motivasi Berhenti Merokok } & \multirow{3}{*}{$P$} & \multirow{3}{*}{$r$} \\
\hline & \multirow{2}{*}{$\begin{array}{l}\mathrm{PC} \\
\mathrm{PC}\end{array}$} & \multicolumn{2}{|l|}{$\mathrm{C}+\mathrm{P}$} & \multicolumn{2}{|l|}{$\mathrm{A}+\mathrm{M}$} & & \\
\hline & & $\mathrm{C}$ & $\mathrm{P}$ & A & $\mathrm{M}$ & & \\
\hline Uang Saku & $\begin{array}{l}1-2 \\
\text { juta/bln }\end{array}$ & $\begin{array}{l}1-2 \\
\text { juta/bln }\end{array}$ & $\begin{array}{l}1-2 \\
\text { juta/bln }\end{array}$ & $\begin{array}{l}1-2 \\
\text { juta/bln }\end{array}$ & $\begin{array}{l}<1 \\
\text { juta/bln }\end{array}$ & $0,416^{(1)}$ & - \\
\hline $\begin{array}{l}\text { Pengeluaran } \\
\text { untuk Merokok }\end{array}$ & 20.000 & 16.500 & 15.000 & 7.500 & 0 & $0,000 *(1)$ & $-0,339$ \\
\hline $\begin{array}{l}\text { Jumlah Batang } \\
\text { Rokok per hari }\end{array}$ & 12 & 8 & 5 & 1,5 & 1 & $0,000 *(1)$ & $-0,477$ \\
\hline $\begin{array}{l}\text { Jumlah Teman } \\
\text { Merokok }\end{array}$ & $46(28,40)$ & $63(38,59)$ & $39(24,07)$ & $8(4,92)$ & $6(3,71)$ & $0,734^{(2)}$ & - \\
\hline $\begin{array}{l}\text { Keberadaan } \\
\text { Perokok di } \\
\text { Tempat Tinggal }\end{array}$ & $65(28,4)$ & $63(38,8)$ & $39(14,1)$ & $8(4,0)$ & $6(3,7)$ & $0,506^{(2)}$ & - \\
\hline $\begin{array}{l}\text { Intensitas } \\
\text { Merokok }\end{array}$ & $46(28,39)$ & $63(38,88)$ & $39(24,06)$ & $8(4,92)$ & $6(3,71)$ & $0,000 *(2)$ & \\
\hline $\begin{array}{l}\text { Rata-rata skor } \\
\text { Pengetahuan }\end{array}$ & 5,5 & 6,1 & 6,0 & 6,8 & 6,5 & $\begin{array}{l}0,085^{(2)} \\
\left(0,021^{\#}\right)^{(2)}\end{array}$ & \\
\hline
\end{tabular}

(1) = Uji beda dilakukan menggunakan Kruskal-Wallis Test

(2) = Uji beda dilakukan menggunakan Chi Square Test

uji korelasi dilakukan menggunakan Spearman Correlation, Uji; P = nilai signifikansi, r: nilai koefisien korelasi

*Berpengaruh signifikan $(\mathrm{p}<0,05)$; " analisis hubungan skor pengetahuan dengan motivasi 3 kategori yaitu Precontemplation (PC); Contemplation $(C)+$ Preparation $(P) ;$ Action $(A)+$ Maintenance $(M)$. 


\section{KESIMPULAN}

Motivasi untuk berhenti merokok dapat dipengaruhi oleh berbagai macam faktor. Berdasarkan hasil penelitian ini, didapatkan bahwa uang saku bulanan, jumlah teman yang merokok, dan keberadaan perokok di tempat tinggal responden merupakan faktor yang tidak berpengaruh secara signifikan terhadap motivasi untuk berhenti merokok. Faktor lain, seperti pengeluaran untuk merokok, jumlah batang rokok yang dikonsumsi per hari, intensitas merokok, dan pengetahuan terkait bahaya merokok berpengaruh secara signifikan terhadap motivasi berhenti merokok.

\section{DAFTAR PUSTAKA}

Ardita, H. (2016). Faktor-Faktor yang Mempengaruhi Motivasi Berhenti Merokok pada Mahasiswa Teknik Mesin Universitas Muhammadiyah Yogyakarta Angkatan 2015. Skripsi; Fakultas Kedokteran dan Ilmu Kesehatan Universitas Muhammadiyah Yogyakarta, Yogyakarta.

Cahil, K., Lancaster, T. \& Green, N. (2010). StageBased Interventions for Smoking Cessation (Review). Chichester: Cochrane Database of Systematic Reviews.

Canadian Cancer Society. (2013). For Smokers Who Want to Quit-One Step at a Time. Kanada: Canadian Cancer Society.

CDC. (2018). What Are the Risk Factors for Lung Cancer by CDC. https://www.cdc.gov/cancer/lung/basic_info/risk _factors.htm. Accessed: 7 Maret 2018.

Diclemente, C., Prochaska, J. O. \& Marden, V. M. (1991). The Process of Smoking Cessation: An Analysis of Precontemplation, Contemplation, and Preparation Stages of Change NIAAA Career Development Award: Within-and PostSession Change Mechanisms in Treatment for Alcohol Use Disorders View project. Journal of Consulting and Clinical Psychology; 59; 295304.

Etter, J. F. \& Sutton, S. (2002). Assessing "Stage of Change" in Current and Former Smokers. Addiction; 97; 1171-82.

Güngörmüs, Z. \& Erci, B. (2012). Transtheorethical Model-Based Education Given for Smoking Cessation in Higher School Students. The Southeast Asian Journal of Tropical Medicine and Public Health; 43; 1548-1559.

Hatsukami, D. K., Lindsay, F. S. \& Prakash, C. G. (2008). Tobacco Addiction. Lancet; 371; 20272038.
Helen, G. St., Neal, L. B., Katherine, M. D., Christopher, H., Margaret, P. \& Peyton, J. (2015). Nicotine and Carcinogen Exposure After Water Pipe Smoking in Hookah Bars. Cancer Epidemiology, Biomarkers \& Prevention; 23; 1055-1066.

Jacob, P., Abu, R. A. H., Dempsey, D., Havel, C., Peng, M., Yu, L. \& Benowitz, N. L. (2014). Comparison of Nicotine and Carcinogen Exposure with Waterpipe and Cigarette Smoking. Cancer Epidemiology, Biomarkers \& Prevention; 22; 765-772.

Kementerian Kesehatan RI. (2015). Perilaku Merokok Masyarakat Indonesia. Jakarta: Pusat Data dan Informasi Kementerian Kesehatan RI.

Pickett, W. \& Bains, N. (1998). Staging of Adult Smokers According to the Transtheoretical Model of Behavioural Change: Analysis of an Eastern Ontario Cohort. Canadian Journal of Public Health; 89; 37-42.

Prochaska, J. O. \& Diclemente, C. (1984). The Transtheoretical Approach: Crossing Traditional Boundaries of Therapy. Florida: Krieger Publishing.

Raju, P., George, R., Ve, R. S., Arvind, H., Baskaran, M. \& Vijaya, L. (2006). Influence of Tobacco Use on Cataract Development. British Journal of Ophthalmology; 90; 1374-1377.

Rau, J. (2002). Respiratory Care Pharmacology (6th edition). New York: Mosby Inc.

Robinson, L. M. \& Vail, S. R. (2012). An Integrative Review of Adolescent Smoking Cessation Using the Transtheoretical Model of Change. Journal of Pediatric Health Care; 26; 336-345.

Sarbandi, F., Niknami, S., Hidarnia, A., Hajizadeh, E. \& Montazeri, A. (2013). The Transtheoretical Model (TTM) Questionnaire for Smoking Cessation: Psychometric Properties of the Iranian Version. BMC Public Health; 13; 1186.

Sieminska, A., Krzysztof, B., Ewa, J., Katarzyna L., Romana, U. \& Marta, C. (2008). Patterns of Motivations and Ways of Quitting Smoking Among Polish Smokers: A Questionnaire Study. BMC Public Health; 8; 1-9.

Velicer, W. F, Gregory, J. N., Joseph, L. F. \& James, O. P. (1999). Testing 40 Predictions From the Transtheoretical Model. Addictive Behaviors; 24; 455-469.

WHO. (2015). WHO Global Report On Trends In Prevalence Of Tobacco Smoking 2015. Geneva: WHO. 
WHO. (2016). Diabetes Country Profile Indonesia. WHO; 48; 18882A-18882B.

WHO. (2018). Heart Disease and Stroke are the Commonest Ways by Which Tobacco Kills
People.

http://www.searo.who.int/tobacco/data/ino_rtc_r eports. Accessed: 27 Maret 2018. 